\section{VARIED THRUSH REPORTED NEAR WOLSELEY}

by Don Hayward, Wolseley

Since reading in the last issue of the Blue Jay of the sighting of a Varied Thrush in Regina, I thought I should report seeing one in the Qu'Appelle Valley last May 24 (1964). I was alone in the valley northeast of Wolseley checking my cattle but was equipped with my binoculars and Field guide to western birds. I was attracted to this bird by its song which I knew immediately was new to me. Working my way closer to where the notes came from I had a real surprise when this thrush appeared. I quickly opened my guide and had a good look, and then looked back at the bird. I came away thrilled and with no doubt in my mind that I had seen a Varied Thrush. I only regret being alone at the time. A hike in the valley is alway a rewarding experience.

\section{UNUSUAL FEEDING BEHAVIOUR OF YELLOWLEGS}

\author{
by Sig $\mathbf{O}$. Jordheim, White Bear
}

During late August or possibly early September of 1963, I was quite surprised to see a flock of Greater Yellowlegs washing their food before eating it. While hauling water from a dam, I noticed seven Greater Yellowlegs chasing and picking insects on the grade side of the dam, then running to the water's edge and dipping their bills in several times. As I had my binoculars along I soon had a close up view and sure enough the yellowlegs were catching crickets, and not once did I see one swallowed before being dunked from one to seven times, usually three or four times. This happened in every case even though some of the crickets were caught as much as 20 feet from the water's edge. I am quite positive the birds were the Greater Yellowlegs and the crickets were our ordinary black field crickets. The top of the grade had numerous cracks from the dry weather, and there were rocks, sticks, and small willows between this area and the water level, so crickets were quite abundant there. There were no sloughs in our area that year, and all dams and dug-outs were low, so the yellowlegs may have been pressed for food.

\section{MARSH HAWK PREYS ON COTTONTAILS}

by Spencer G. Sealy, Edmonton

While reading the report by $J$. B. Millar (Blue Jay, 22:148) which records the attempt of an adult female Marsh Hawk (Circus cyaneus) (not hudsonius, as given by Millar) to drag the carcass of a coot, probably at least equal to its own weight, a record I have of the Marsh Hawk apparently taking heavy prey immediately came to my mind. During a study of Marsh Hawk reproductive biology in the Brooks area of southeastern Alberta, May through July, 1964, data on prey fed to the young were recorded. In one nest, situated in a cattail marsh with about 15 inches of water, four young were raised whose food during their 35-day development period as nestlings was comprised of 14.29 per cent Nuttall's Cottontail (Sylvilagus nuttallii). The hind feet and heads of 10 rabbits were collected and measured (average, H.F. -92.5 mm., Ear-60.0 mm.). I checked their measurements with specimens in the University of Alberta Department of Zoology mammal collection and found them comparable to those of nine adult specimens whose average weight was 984.0 grams.

It is interesting to note here that as the Marsh Hawk's nest was approximately 40 feet out in the marsh, it would be necessary for this prey to be carried above the cattails to the nest, for dragging them was seemingly impossible. Perhaps the rabbits were partly eaten when captured and then the lighter remains carried to the young, for I never found a complete carcass in the nest, usually just the feet, head, and vertebral column.

\section{SUMMER MEETING}

Don't forget the SNHS Summer Meeting which will be held this year at attractive Candle Lake. The dates are June 11, 12, 13 (Friday evening through to Sunday). The responsibility for arrangements and programme has been assumed by the Prince Albert Natural History Society, and since they have been making plans for several months, we know we shall have a good meeting. 